Currículo sem Fronteiras, v. 20, n. 2, p. 416-441, maio/ago. 2020

\title{
EDUCAÇÃO POLÍTICA DA MEMÓRIA E ARTE CONTEMPORÂNEA
}

\author{
Claudia Prado Fortuna \\ Universidade Estadual de Londrina - UEL
}

\begin{abstract}
Resumo
O objetivo principal deste artigo é discutir as contribuições da arte contemporânea para uma educação política da memória no âmbito do ensino da História, considerando os usos do passado e as experiências estéticas da arte nos processos de constituição do pensamento histórico. Com este propósito, apresento algumas séries das obras das artistas plásticas contemporâneas Rosângela Rennó, Leila Danziger e Adriana Varejão, localizando as estratégias estéticas e modos de inserção das artistas no campo da memória e de narrativas a contrapelo (W.Benjamin). Interessou-me uma aproximação com os procedimentos que garantem a experiência estética da arte (política da arte) como aquela capaz de instalar a eficácia de um dissenso - o conflito de vários regimes de sensorialidades (J.Rancière). Ao problematizar os procedimentos metodológicos e a força explicativa da arte contemporânea para apresentar o real, questões de memória foram trazidas à tona e se tornaram legíveis nos processos de constituição do pensamento histórico.
\end{abstract}

Palavras- chave: educação política da memória, arte contemporânea, ensino da História

\begin{abstract}
The main purpose of this article is to discuss the contributions of contemporary art on behalf of a political education of memory in the scope of History teaching, taking into account usages of the past and the aesthetic experiences of art in the processes of historical thought formation. In order to achieve this aim, I present some series of works produced by the contemporaneous visual artists Rosângela Rennó, Leila Danziger and Adriana Varejão, pointing out the aesthetic strategies and the artists' insertion manners in the field of memory and narratives against the grain (Walter Benjamin). I was particularly interested in a convergence with the procedures which assure the aesthetic experience of art (art politics) as the one capable of installing the effectiveness of a dissention - the conflict of various sensorial regimes (Rancière). When the methodological procedures and the explanatory strength of contemporary art are questioned to show the real, matters of memory were highlighted and became themselves readable within the process of historical thought formation.
\end{abstract}

Keywords: political education of memory, contemporary art, History teaching 


\section{Introdução}

No artigo - O Choro Triste da História - publicado na Revista Cult de 03/2017, o professor Gustavo Silveira Ribeiro apresenta e analisa o livro/poema/site - Tróiades - remix para o próximo milênio ${ }^{1}$, do poeta Guilherme Gontijo Flores. Para Ribeiro, o projeto estético deste trabalho atua em diferentes frentes: na interpretação e tradução livre de três tragédias clássicas, Troiades (415 a.C) e Hecuba (424 a.C), de Eurípedes e Troades (c.54-64 d.C), de Sêneca, na seleção de imagens de acontecimentos históricos traumáticos e no recorte de trechos da nona tese Sobre o conceito da história (1940), de Walter Benjamin. Ele considera que, como na constituição de um mosaico, os acontecimentos traumáticos ocorridos em temporalidades diversas (do século II a.C até 1945, de forma não cronológica) são acolhidos pelos poemas de Flores e, nos lamentos do passado, escutamos os ecos e urgências do nosso presente histórico. Deste modo, nas palavras de Ribeiro (2017, p. 3),

o genocídio armênio, a colonização da América ou a escravidão negra vivem também nas ruínas de Tróia, que as prenunciavam, e a dor de Hecuba é também o sofrimento das mães e viúvas de Canudos, bem como das mães dos assassinados do Carandiru.

A percepção dessa temporalidade não linear se confirma a cada instante quando no trabalho disponível on-line, juntamente com as imagens e poemas de Gontijo, nossos sentidos se veem envolvidos pela obra musical Genocide - Symphonic Holocaust ${ }^{2}$, e lá permanecemos elaborando o luto. Nos lamentos do passado, somos levados, pela mão do poeta, a escutar os ecos e urgências do nosso presente histórico numa sobreposição de tempos e de memórias capaz de provocar deslocamentos nas narrativas oficiais.

Importante registrar que da mesma maneira que Tróiades nos lança a um percurso de temporalidades diversas marcadas pela barbárie, muitos outros artistas contemporâneos têm buscado em suas poéticas os rastros de memórias do sofrimento acumulado como núcleo aglutinador de suas apresentações. $\mathrm{Na}$ contramão do silenciamento inerte sobre inúmeros momentos dramáticos da nossa história, a produção contemporânea das artes tem assumido para si, independente de linguagens ou suportes, a leitura da cultura como marcada pela violência e tem se voltado para as questões de memória, de re/escritura, de construção de outras narrativas, muitas delas em sintonia com a renovação historiográfica ${ }^{3}$ vigente nas últimas décadas do século XX.

É no contexto dessas reflexões sobre a memória e da inscrição da violência ${ }^{4}$ nas manifestações artísticas que este artigo se aproximou de algumas elaborações estéticas do período pós-década de 1970 para localizar seus vínculos com narrativas a contrapelo ${ }^{5}$. Através de uma investigação enraizada na dimensão teórica da arte contemporânea (pensamento, ideias e conceitos veiculados pela obra), buscou-se definir pressupostos de novas reflexões e abordagens para uma educação histórica ${ }^{6}$ capaz de redesenhar o espaço, reconfigurar a experiência comum do sensível e promover uma relação viva com o passado. Ao iluminar os procedimentos metodológicos e a força explicativa da arte contemporânea 
para expressar o real, buscamos, no âmbito deste artigo, as estratégias pelas quais o passado é reinterpretado a partir do tempo presente sob a forma de experiências estéticas. Em um modelo não linear, parte da arte contemporânea metamorfoseia histórias traumáticas de um passado recente em imagens que pedem para ser lidas e em vozes que querem ser escutadas. Em outras palavras, o que é desprovido de lugar encontra abrigo na resistência da memória.

\section{Direitos humanos e memórias conflitantes}

No seu livro, "Culturas do passado-presente", Huyssen (2014) considera que os vários estudos contemporâneos da memória têm como característica importante consolidar seu compromisso com os direitos humanos tanto em termos discursivos quanto práticos e assim impedir exercícios vazios de memória, sobretudo da memória traumática. Fortalece-se a consciência de que apenas a memória das violações dos direitos do homem pode fornecer um elo substancial entre passado e futuro e assim garantir o futuro desses direitos.

Neste sentido, o foco nos depoimentos e testemunhos na constituição e compreensão dos traumas históricos e a força das lembranças individuais de violações de direitos humanos são agora capazes de impedir que os discursos sobre esses direitos se tornem uma abstração histórica. Para ele,

O discurso dos direitos humanos e culturais deve apoiar-se em exemplos concretos de violações dos direitos, interpretados nos contexto de situações sistêmicas e histórias antigas, e pode ser respaldado por obras de arte que treinem nossa imaginação não só para reconhecer o que Susan Sontag chamou de dor alheia, mas também para construir remédios jurídicos, políticos e morais contra proliferação desenfreada dessa dor (HUYSSEN, 2014, p. 205).

Portanto, os debates contemporâneos sobre a memória expressos na literatura, na arquitetura e nas artes plásticas ganham destaque no sentido de fortalecer as diversas estratégias de sobrevivência de rememoração pública da violência histórica, política e social. De acordo com Assmann (2011), a arte em geral passou a abordar o tema da memória nos anos de 1970 pelas mais diversas motivações. Na Alemanha, por exemplo, além do dever de memória com seu passado traumático, a lembrança se reveste de um potencial político de resistência ao esquecimento e à supressão desse passado. Uma característica importante e singular das questões de memória no século XX, nas palavras da autora, está em que a nova arte sobre a memória "não precede, mas sim sucede ao esquecimento" (Assmann, 2011, p.386), ou seja, os artistas que trabalham com a memória chegaram à cena da catástrofe depois de ela ter acontecido e o que fica é apenas recolher os restos e os vestígios do que sobrou. Para a autora, essa geração de artistas que nasceu durante ou logo depois da Segunda Guerra Mundial só conheceu um ambiente marcado pelas ruínas e pelas tentativas de reconstrução. Neste ambiente, a lembrança ganha um poder subversivo que se impõe a 
qualquer forma de esquecimento. Logo, não se trata de um trabalho de documentação, mas de um inventário das perdas. De construir um arquivo a partir do lixo.

Ao também refletir sobre a memória traumática na contemporaneidade, Beatriz Sarlo (2007) considera que a proliferação de narrações-histórias de vida, entrevistas, memórias, relatos identitários e memorialísticos- surge como possibilidade de superação da alienação, do trauma e da coisificação dos fatos, já que é pela dimensão subjetiva dessas narrativas que se torna possível fornecer sentidos à experiência. A autora também considera que a questão da restauração da experiência como memória ou, dito de outra maneira, o relato da experiência entendido como representação verdadeira, deve ser melhor examinado. Como exemplo, a autora retoma a questão trazida pelos formalistas russos do século $\mathrm{XX}$, que indicavam que qualquer representação só seria possível pela ruptura reflexiva com o imediatismo da experiência e das percepções. Eles consideravam que,

a arte tem condições de iluminar o que nos cerca de modo mais imediato, contanto que se produza um corte por distanciamento, que desvie a percepção de seu hábito e a arranque do solo tradicional do senso comum. O questionamento do que é costumeiro é a condição de um conhecimento dos objetos mais próximos, que ignoramos justamente porque permanecem ocultos pela familiaridade que os encobre. Isso vale também para o passado (SARLO, 2007, p.41).

Neste sentido, é possível pensar, como Sarlo, que a tentativa de recuperar o que foi perdido e reprimido pela violência do Estado induz, muitas vezes, a uma relação afetiva e moral com o passado pouco compatível com o distanciamento também necessário ao oficio do historiador. Ou seja, é importante verificar o quanto a memória acaba de fato por impor uma visão de passado sem discussão ou confrontação crítica, confirmando uma falsa equivalência entre o direito de lembrar e a verdade da lembrança.

Em perspectiva diferente à da autora, Huyssen (2014) defende que o necessário distanciamento do historiador com relação ao passado não anula o fato de que toda a lembrança está sujeita a interesses, usos específicos, pontos cegos e evasões. Para ele, os conflitos entre memória e historiografia, bem como a ideia de memória coletiva baseada em Maurice Halbwachs e Pierre Nora, acabam por apagar o conflito entre campos de memórias rivais, entre batalhas de passados, não apenas no campo circunscrito da memória nacional, mas na competição entre campos de memória separados pelo espaço e pelo tempo. Para ele,

A ideia largamente popular de memória coletiva, baseada que é nos escritos sociológicos e históricos de Maurice Halbwachs e Pierre Nora, bloqueia o discernimento dessas batalhas do passado, que tanto são travadas dentro das nações quanto em contextos transnacionais. Ela impede a compreensão do exemplo normal de qualquer política da memória em que passados diferentes são colocados um contra os outros (HUYSSEN, 2014, p. 182).

Assim, ao apontar para a não-neutralidade da memória, Huyssen (2014) questiona a falsa dicotomia entre a memória como autêntica, afetiva e a história como objetiva e neutra. 
Reforça a posição de que, ao se trabalhar com a memória, não podemos fugir de nossa própria inserção histórica, já que os usos do passado são sempre presentes, ou seja, o passado é produzido no presente e ele tem um impacto inevitável sobre o que rememoramos. Por conseguinte, o que ganha forma é o conceito de memórias conflitantes. Memórias conflitantes não apenas no campo delimitado da memória nacional, mas também a competição de memórias em espaços e temporalidade diferentes que, para ele "tentam deslocar ou suplantar uns aos outros a partir de uma situação de privilégio" (Huyssen, 2014, p.183).

\section{O passado como fato de memória}

Ao longo de todo o século XX, ficou patente a violência que acompanhou o nosso processo civilizatório, tempo marcado por guerras, genocídios, campos de concentração, torturas e tantas outras formas de violência física e psicológica que, de certa forma, abalaram as grandes narrativas que procuravam dar sentido à história. Para responder ao que foi vivido pelas sociedades pós-totalitárias e pós-ditaduras, artistas contemporâneos buscam em suas poéticas contra-arquivar a barbárie e escavar novos sentidos para as narrativas existentes.

Como exemplo,Seligmann-Silva (2014a) cita a Documenta, renomada exposição internacional de arte contemporânea realizada a cada cinco anos na cidade alemã de Kassel. Com curadoria de Roger Buergel e o título de "Migração da Forma", a Documenta 12, de 2007, apresentou a coleção e o arquivo como um dos seus temas principais e a imagem que serviu de mote para os trabalhos apresentados foi a pintura Angelus Novus, de Paul Klee ${ }^{7}$, imagem icônica da reflexão de Walter Benjamin sobre o nosso processo histórico enquanto um processo de barbárie.

O quadro é uma pintura feita a nanquim, giz pastel e aquarela sobre papel que Benjamin adquiriu em Munique em 1921 e que se encontra hoje no Museu de Israel em Jerusalém. Na sua nona tese, Sobre o conceito da história de 1940, Walter Benjamin (1985), registrou todas as observações que essa imagem de Paul Klee lhe possibilitou para construir uma poderosa alegoria do processo histórico. Nas suas palavras,

Há um quadro de Klee que se chama Angelus Novus. Representa um anjo que parece querer afastar-se de algo que ele encara fixamente. Seus olhos estão escancarados, sua boca dilatada, suas asas abertas. $\mathrm{O}$ anjo da história deve ter esse aspecto. Seu rosto está dirigido para o passado. Onde nós vemos uma cadeia de acontecimentos, ele vê uma catástrofe única, que acumula incansavelmente ruína sobre ruína e as dispersa a nossos pés. Ele gostaria de deterse para acordar os mortos e juntar

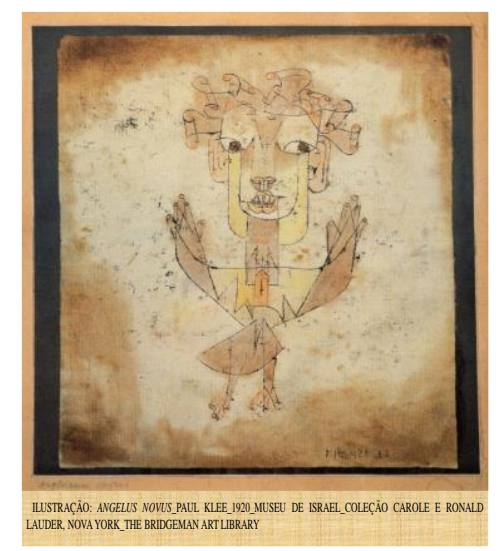


fragmentos. Mas uma tempestade sopra do paraíso e prende-se em suas asas com tanta força que ele não pode mais fechá-las. Essa tempestade o impele irresistivelmente para o futuro, ao qual ele vira as costas, enquanto o amontoado de ruínas cresce até o céu. Essa tempestade é o que chamamos de progresso (BENAMIN,1985, p.226)

Nessa imagem, frente ao acúmulo de violência e destruição, o anjo da história parece não conseguir escapar do tempo homogêneo e vazio que o impulsiona em direção ao progresso. Ele gostaria de parar, cuidar das vítimas que se encontram sob os escombros amontoados, nomear os mortos, mas a tempestade o impele a continuar e apenas olhar para o passado. Onde se vê uma sequência linear de acontecimentos, o anjo vê a catástrofe, as ruínas, as mortes. Mas, a partir dessa imagem, o anjo da história também deve ser capaz de se reposicionar, interromper o continuum da história, escová-la a contrapelo e, assim, salvar do esquecimento a memória da barbárie que se acumula sem cessar.

Este gesto de interromper a história que se conta para poder lembrar-se dos sofrimentos esquecidos, se difere para Benjamin, como considera Gagnebin (1999), de qualquer pensamento utópico no qual o passado comporta imagens ideais carregadas de sentido futuro. O que conta é subverter "o ordenamento tranquilo do discurso estabelecido" pela produção de rupturas eficazes.

A novidade dessa maneira de pensar a história é que ela não parte dos fatos passados, mas do movimento de lembrá-los e de construí-los no saber presente do historiador. Assim a ideia do passado como fato objetivo passa a ser a ideia do passado como fato de memória. Lembrar seria não o processo de conservar o passado tal como ele aconteceu, mas sua transformação ativa do presente.

\section{A imagem dialética do despertar}

Nas notas concernentes à Teoria do Conhecimento, Teoria do Progresso, da obra Passagens, Benjamin (2007) indica como procedimento metodológico da história a necessidade de recolher sinais e traços sobreviventes nas ruínas do passado para realizar com eles uma constelação. Para Benjamin, essa constelação se constitui quando o que passou encontra o agora em uma imagem dialética com potencialidades cognitivas que se identifica com a ideia de despertar. Nas suas palavras,

Não é que o passado lança sua luz sobre o presente ou que o presente lança sua luz sobre o passado, mas a imagem é aquilo em que o ocorrido encontra o agora num lampejo, formando uma constelação. Em outras palavras: a imagem é a dialética na imobilidade, pois enquanto a relação do presente com o passado é puramente temporal e contínua, a relação do ocorrido com o agora é dialética não é uma progressão, e sim uma imagem, que salta (BENJAMIN, 2007,p. 504). 
Por que uma imagem? Para Didi-Huberman (2015), Benjamin considerava a imagem como o fenômeno originário da apresentação histórica porque ela seria capaz de reunir e fazer explodir "modalidades ontológicas contraditórias" (Didi-Huberman, 2015, p.127) como presença/representação; o devir daquilo que muda/a impotência do que permanece. Portanto, a imagem autêntica seria sempre uma imagem dialética que fulgura. Uma imagem não como imitação de algo, mas como um intervalo que se torna visível, podendo ser material e psíquica, externa e interna ao mesmo tempo e sua potência está na ideia do despertar e do limiar.

A imagem seria, portanto, afirma Didi-Huberman (2011), um operador político de protesto e de emancipação naquilo que se revela "capaz de transpor o horizonte das construções totalitárias" (Didi-Huberman,2011,p.218) e um operador temporal de sobrevivências relativas ao nosso passado, ao nosso presente e, logo, ao nosso futuro. Daí a importância de se interromper a história para ir ao encontro das imagens sobreviventes, dos lampejos de pensamentos, das ressurgências que chegam até nós, como um legado, tal como "a menor borboleta esboçada por Marika Froedmanova sobre um papel amarelado, no campo de Theresienstadt" (Didi-Huberman, 2011, p.133), pouco antes de ser deportada e morta em Auschwitz com 11 anos de idade. Ou ainda, como as experiências muitas vezes clandestinas registradas pelas filmagens de refugiados afegãos ou iraquianos que tentavam atravessar o túnel sob o canal da Mancha para chegar à Inglaterra, imagens feitas por Laura Waddngton na escuridão da noite e sob a luz implacável dos helicópteros da polícia.

Embora não seja possível ver muita coisa, o filme ilumina, como nos diz DidiHuberman,"parcelas de humanidade", imagens movidas pela urgência da fuga, imagenslampejo, imagens no limiar do desaparecimento:

O que aparece nesses corpos da fuga não é mais do que a obstinação de um projeto, o caráter indestrutível de um desejo. O que aparece é também a graça, às vezes: graça que contém todo o desejo que toma forma. Belezas gratuitas e inesperadas, como quando esse refugiado curdo dança na noite, ao vento, tendo seu cobertor como única vestimenta: este é o ornamento da dignidade e, de certa forma, de sua alegria fundamental, sua alegria apesar de tudo [...] (DIDI-HUBERMAN, 2011, p. 157).

Mas, o que fazer para que essas imagens permaneçam? Como afirma Gagnebin (2014), é necessário um trabalho crítico da memória, gesto de cesura que caracteriza a tarefa do historiador que busca uma imagem frágil, involuntária, inconsciente: "um elemento soterrado pelo hábito, algo esquecido ou negligenciado" (Gagnebin, 2014, p. 242). Talvez uma promessa que não foi cumprida, mas que o presente pode reconhecer e retomar. Algo de sobrevivente se torna visível na cesura aberta pelo processo de memória na aproximação sempre dialética com o que resta e com o agir, apesar de tudo.

Trata-se, portanto, de um gesto consciente de interrupção que coloca em questão a temporalidade da memória dominante. O gesto é, desse modo, político: buscar por desvios reflexivos a partir de novos pressupostos teórico-metodológicos que possibilitem ler e 
escrever outras histórias. O propósito não é o de analisar os grandes sistemas que ficaram do passado, mas as pequenas coisas que sobraram de um processo de destruição.

\section{Estéticas da memória: Rosângela Rennó, Leila Danziger e Adriana Varejão}

O campo teórico da arte contemporânea tem conseguido, nas suas diversas poéticas, expressar uma ética intransigente e um posicionamento político crítico em relação à nossa história e ampliar as discussões sobre os princípios epistemológicos e metodológicos na confluência entre a experiência do passado e os fatos atuais. O que está em questão na arte não é a comprovação da verdade, mas, sim, a instauração de uma verdade e o trabalho estético das artistas selecionadas nos aproximou do conceito de memória a contrapelo como possibilidade de acesso a outras temporalidades e a outras narrativas históricas.

Neste campo de referências, confirmamos as produções estéticas como formações históricas e sociais que originam discursos capazes de revelar a movimentação de sentidos, as batalhas de percepções, as ambivalências e outras sensibilidades na sua relação com a história, a memória e a temporalidade. Ou seja, muitas das elaborações artísticas contemporâneas, por possibilitarem a insurgência de memórias a contrapelo, provocam deslocamentos nas narrativas e apresentam elementos fundantes de novas reflexões e abordagens sobre o nosso passado.Diante dos eventos-limite que acompanham a história do Brasil, como violência policial, repressão aos movimentos sociais, ditaduras, torturas, diversas formas de opressão, ou seja, frente ao acúmulo de violência na nossa experiência histórica, é possível pensar em outras formas de abordagem das fontes onde os documentos passam a ser problematizados enquanto testemunhos da barbárie.

\section{Rosângela Rennó}

Rosângela Rennó nasceu em Belo Horizonte em 1962. Formou-se em arquitetura pela Universidade Federal de Minas Gerais em 1986 e em artes plásticas pela Escola Guignard em 1987. Também é doutora em Arte pela Escola de Comunicações e Artes da Universidade de São Paulo. Os projetos artísticos contemporâneos de Rennó testemunham o passado, revelam o esquecimento e a amnésia social e, de acordo com Herkenhoff (1996 a,), a geração de Rosângela Rennó (que surgiu depois da abertura política dos anos de 1980) vincula grande parte dos seus projetos a uma certa "estética do desaparecimento" (Herkenhoff, 1996, p.6) e a uma fenomenologia poética e politizada do olhar. Sua forma de expressão é quase sempre a fotografia, embora, raramente, realize suas próprias fotos. Na maioria das vezes, prefere se estabelecer nas imagens já existentes e trabalhar com negativos encontrados em arquivos, fotografias de jornais, fotos de obituários e de identificação criminal.

No seu trabalho Imemorial, instalação feita para a exposição Revendo Brasília, produzida no ano de 1994, Rennó localizou várias fotografias, a partir de uma pesquisa realizada no "Arquivo Público do Distrito Federal", que pertenciam à Empresa Novacap, 
companhia urbanizadora responsável pela construção de Brasília. Neste arquivo abandonado, selecionou 50 fotos 3x4 de operários, conhecidos como candangos, que trabalharam na construção da cidade. As fotos, já bastante deterioradas, foram ampliadas nas dimensões 60x40x2cm com intervenções em tons claros e escuros e depois foram distribuídas em bandejas de ferro e parafusos em um processo de apropriação e subversão do seu logos. Numa longa parede e no piso à sua frente, foram fixadas as imagens de tonalidade mais clara e, expostas no chão, as de tons mais escuros.

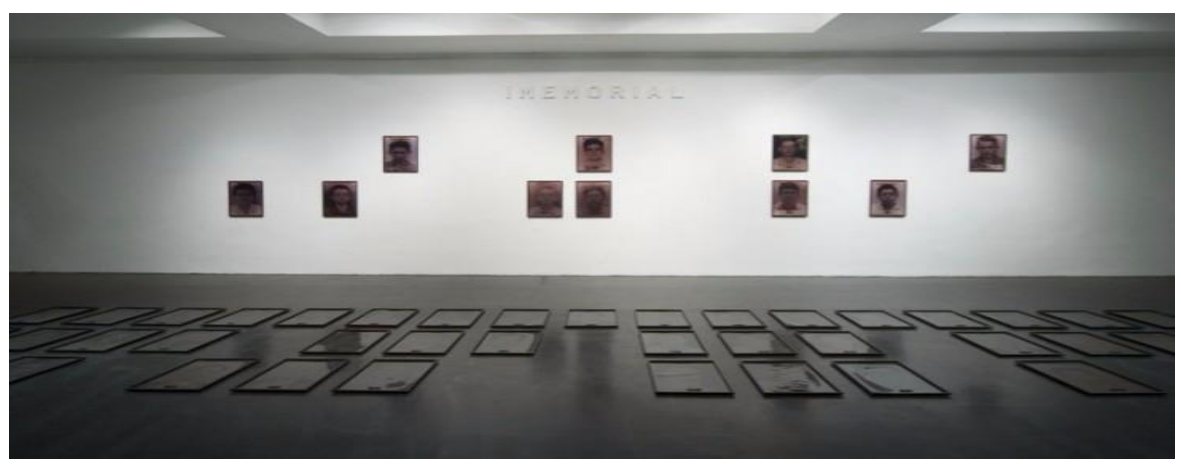

Figura 1 - Imemorial,1994. 40 Retratos sobre bandejas de ferro e parafusos (60 x 40 x $2 \mathrm{~cm}$, cada). Título Imemorial na parede em letras de metal pintado Galeria Athos Bulcão. Coleção Marcos Vinícius Vilaça. http://www.rosangelarenno.com.br/obras/view/19/1

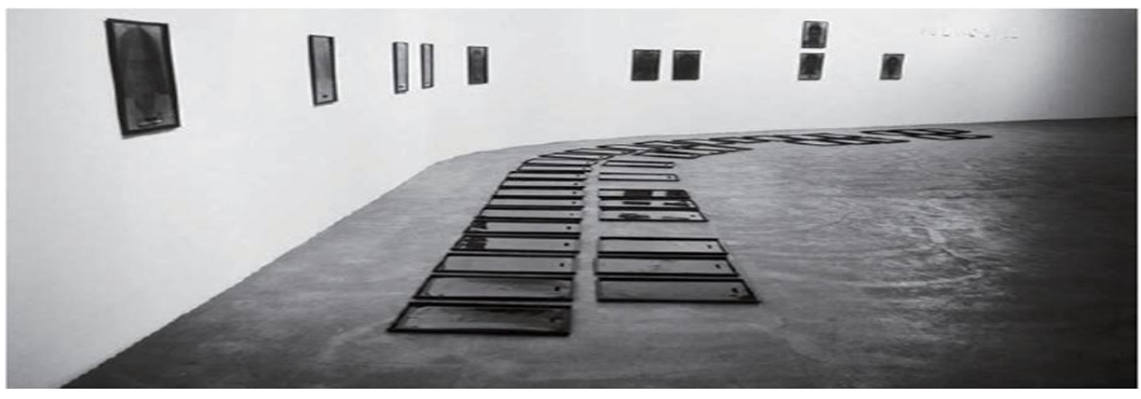

Figura 2 - Instalação para a exposição "Revendo Brasília" . 60 × 40 × 2 cm (cada moldura de ferro). Coleção de Marcos Vinícius Vilaça (Brasília/Recife). Série Imemorial,1994. http://www.rosangelarenno.com.br/obras/view/19/1

Ao trabalhar com imagens trancafiadas e arquivadas, como destaca Barbarena (2009), o estatuto fotográfico na obra da artista ganha força por sua capacidade de desordenar uma herança cultural dominante, dando lugar ao que não foi considerado digno de ser solenizado. Em outras palavras, as faces dos operários sem nome e as lápides fotográficas dão visibilidade a um passado até então desconsiderado pelos relatos oficiais.

O que vemos são rostos de homens, mulheres e crianças que provavelmente se deixaram fotografar como parte da identificação formal para o trabalho. São expressões sérias, olhares impenetráveis que ganham uma força ainda maior pelo sombreado com que são apresentadas.Como considera Monteiro (2016, p.125), 
Nós os vemos e eles nos olham desse não lugar da história, nos intimando a pensar sobre a sua morte e seu esquecimento social [...]. É como se pudéssemos abrir os seus túmulos e ver novamente os seus rostos vindos do passado e que nos olham no presente. A obra não oferece uma reconstituição de suas identidades ou de suas memórias, apenas as presenças espectrais desses outros que nos falam através de sua ausência (morte e esquecimento social) do que ainda resta saber sobre os que construíram a capital de um desejado país "novo e moderno".

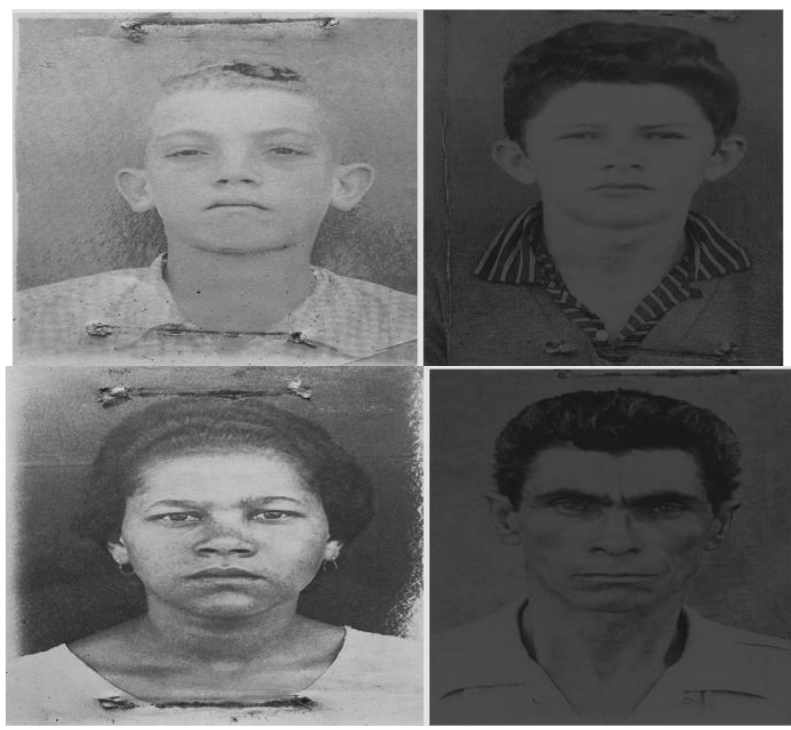

Figura 3 - Série Imemorial, 1994.

http://www.rosangelarenno.com.br/obras/view/19/1

Em Imemorial, Rennó (2015) busca pelas imagens que falam do indivíduo,que falam das margens, que quase vão para o lixo. A intenção, segunda ela, é possibilitar narrativas diferentes daquelas que geraram a imagem; para tanto, recorre a veladuras e apagamentos intencionais "para forçar o espectador a buscar a imagem no limite da visibilidade" (Rennó, 2015, p.15). Ao pintar a parte de trás das fotografias de negro, é como se cada quadro também se transformasse em um espelho onde acabamos por contemplar nosso próprio passado. São imagens periféricas nas quais, ao olharmos de imediato, não encontramos sua marca histórica. Só o olhar mais prolongado, segundo a artista, será capaz de conquistar essa marca histórica.

\section{O que resiste}

Dos operários que morreram na construção de Brasília, nenhum nome nos é revelado, não sabemos quais eram suas funções, o que aconteceu às crianças. Mas, ao olharmos para os semblantes tensos e olhares assustados dos 50 rostos da exposição, somos levados, como 
nos revela dos Anjos (2006), "a imaginar o ambiente e o momento social no qual viveram as suas vidas e as razões da amnésia social para onde seus desejos escaparam" (Anjos, 2006, p. 2).

Podemos considerar que do outro lado da ideologia desenvolvimentista, Rennó ilumina o massacre de trabalhadores da construção civil ocorrido em 1959 no acampamento da construtora Pacheco Fernandes Dantas ${ }^{8}$. No contexto da intensificação das jornadas de trabalho para a inauguração da nova capital, das péssimas condições de vida, com turnos de 18 horas por dia e 90 horas semanais e da péssima qualidade da comida, os operários iniciaram um motim na cantina que terminou com a expulsão, pelos operários, dos policiais da Guarda Especial de Brasília, que faziam a segurança no local. Como resultado desse ato de revolta, no meio da noite, caminhões de soldados cercaram o galpão dos trabalhadores e abriram fogo naqueles que tentaram fugir, acertando também com tiros os barracões onde muitos dormiam. Estima-se de 20 a 50 vítimas fatais que teriam sido enterradas em vala aberta, ao pé da torre de comunicação da cidade. No entanto, como nada foi apurado oficialmente, a história desse massacre foi arquivada.

Para Herkenhoff (1996a), o trabalho de Rosângela Rennó atua como um projeto de luto em que nada escapa ao olhar da artista: ele produz evidências. Com essa exposição, o projeto utópico de Brasília é confrontado com o massacre dos operários e se transforma num monumento fúnebre que "atesta a dissolução dos grandes relatos e de um ponto de vista unitário da história"(Herkenhoff, 1996a, p.32). O próprio título Imemorial, como nos lembra Seligmann-Silva (2014b), remete ao conceito de contramonumento que passou a ser empregado pelos teóricos da memória do Shoah. No caso da história da construção de Brasília, trata-se de denunciar a ideologia desenvolvimentista, desconstruir a falsa utopia daquela capital e, por meio de inversões, nos permitir ver o esquecido. Nas suas palavras,

No caso de Imemorial trata-se de iluminar o outro lado da ideologia desenvolvimentista, do culto cego ao progresso, de mostrar a falsidade da utopiaBrasília, que significou a morte de "candangos", bem como a expulsão dos pobres para as cidades satélite. Rennó nos faz ver o lado distópico daquela capital, ironizando, ao mesmo tempo, de modo crítico, os rituais e memoriais oficiais (arquivos, estes sim, mortos) (SELIGMAN-SILVA, 2014b, p. 41).

Para concluir, podemos afirmar que o caminho estético proposto por Rosângela Rennó se materializa na sequência de escolhas intencionais da pesquisadora/fotógrafa para trazer, do presente para o passado e do passado para o presente, identidades exiladas e relegadas ao esquecimento. Aqui arte e política se encontram para além delas mesmas, fazendo desnaturalizar o que está cristalizado. Por isso, a obra Imemorial remete ao caráter arquivístico do lembrar e do esquecer e ao imperativo crítico de questionamento da narrativa épica da construção de Brasília.

Trata-se de um contra-arquivo dos memoriais oficiais. $\mathrm{O}$ que fica como evidência é a imagem ausente dos silenciados e a possibilidade de reescritura a partir das ruínas, dos traços e rastros deixados pela barbárie.Nesse sentido, nas palavras de Monteiro (2016), a obra 
Imemorial é uma "espécie de antimemorial com uma proposta de reescrever a contrapelo a história da construção da cidade e da nação"(Monteiro, 2016, p. 124). As fotos, apenas identificatórias, se apresentam como rastros de um trabalho de memória daquilo que foi desconsiderado na história da construção de Brasília e se transformam em testemunhas do esquecimento.

\section{Adriana Varejão}

Outra importante artista brasileira contemporânea é Adriana Varejão. Nasceu no Rio de Janeiro em 1964 e começou a sua carreira nos anos 1980 e, a partir de 1983, realizou vários cursos livres na escola de Artes Visuais do Parque Lage (R.J). Sua primeira exposição individual aconteceu em 1989 em Amsterdam e atualmente há um pavilhão dedicado a seu trabalho no Instituto Inhotim em Brumadinho (MG).

A artista elabora sua poética com a tradição da pintura e sua produção traz temas voltados à colonização, ao barroco, à azulejaria, ao corpo e suas vísceras. Nas palavras de Herkenhoff (1996b), a pintura de Adriana Varejão apresenta muitas dimensões e espessuras tanto na sua materialidade como na "densidade simbólica do [seu] discurso pictórico" e a sua poética se realiza na coleta de significantes dispersos, conectados em cenas construídas numa "teatralização da história"(Herkenhoff,1996b, p.1). Herkenhoff considera que:

Varejão sabe que articular historicamente o passado visual significa apropriar-se de uma reminiscência, de uma evidência visual, tal como ela relampeja no momento de um perigo.Nisso sua arte atua como um processo de agenciamento da história (HERKENHOFF, 1996b, p. 2).

Desta ação poética, resulta a instauração de uma sincronia com o presente. Pela inversão de elementos estilísticos e retóricos do barroco, pelo confronto com a densa significação das imagens culturais, Adriana Varejão nos leva a descobrir no vazio e nas suturas um modo de ver o mundo aos pedaços. No seu processo de apropriação e ressignificação pictórica, inventa outro passado visual com sensualidade plástica e várias de suas produções se conectam a histórias marginais, quase esquecidas no agenciamento de outros sujeitos históricos.

\section{Iconografia colonial e a inscrição da violência}

Uma das séries de Adriana Varejão, Terra Incógnita (1991/2012), diz respeito ao processo de violência da colonização do Brasil. Nela, a artista faz uma releitura das obras dos primeiros viajantes europeus que chegaram a essas terras, iluminando a crueldade e a dominação escondida nas representações deixadas por eles. Ao revisitar criticamente esses quadros, a artista reproduz o original e no centro da tela faz incisões ou cortes que deixam entrever uma matéria de coloração vermelha, tal e qual ferida não cicatrizada, aberta, latente, 
dolorida. Um dos quadros trabalhados por Varejão foi o do francês Conde de Clarac (17771847), Floresta Virgem do Brasil, que resultou na obra Paisagem (1995).

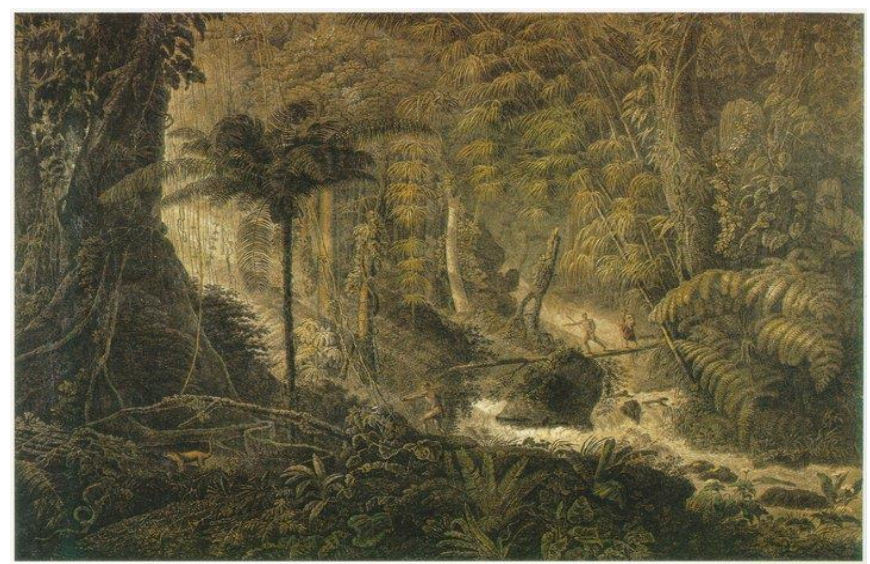

Figura 4 - Floresta virgem do Brasil (1822). Museu Castro Maya, Rio de Janeiro. https://commons.wikimedia.org/wiki/File:Claude-Fran\%C3\%A7ois_Fortier-Floresta_virgem_do_Brasil.JPG

Neste processo, a artista reproduz parte da natureza domesticada da pintura de Clarac, rasura a tela ao meio, permitindo-nos ver outra paisagem, a do Rio de Janeiro que, por sua vez, também é fendida ao meio.Ao olharmos para as duas pinturas, a leitura crítica de Adriana Varejão se revela através de ações estruturadas de apropriação, deslocamento e ressignificação.

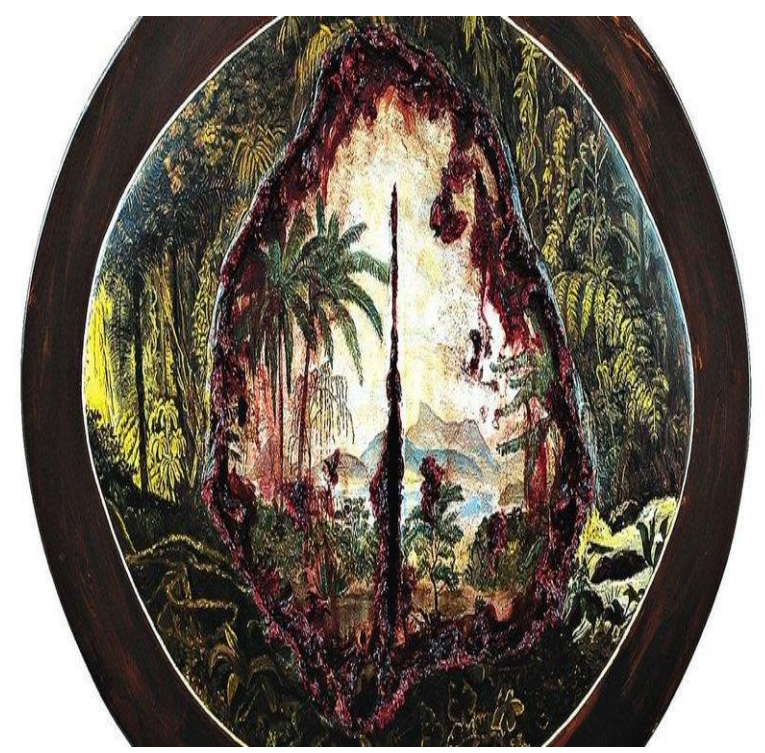

Figura 5 - Adriana Varejão. Paisagens, 1995. Registro fotográfico autoria desconhecida. PAISAGENS . In: ENCICLOPÉDIA Itaú Cultural de Arte e Cultura Brasileiras. São Paulo: Itaú Cultural, 2019.Disponível em: http://enciclopedia.itaucultural.org.br/obra23424/paisagens>. 
Os quadros se revestem de uma dimensão política ao unir o presente ao passado e os rasgos surgem como pequenas citações que, apresentadas fora do seu contexto original, provocam o estranhamento.

Em outros dois trabalhos de apropriação e releitura de imagens coloniais, Carne à Moda de Frans Post (1996) e Carne à Moda de Taunay (1997), Varejão retoma as obras Paisagem em Pernambuco, de Frans Post, artista que veio para o Brasil no século XVII compondo a comitiva do conde Maurício de Nassau e Vista tirada do Morro da Glória, de NicolasAntoine Taunay,artista que integrou a Missão Francesa em 1816 para fundar a Escola de Belas Artes no Rio de Janeiro.

Na reprodução da imagem de Post, a tela é rasgada em pequenos sulcos vermelhos que são oferecidos como nacos de carne em pratos de porcelana das Companhias das Índias.

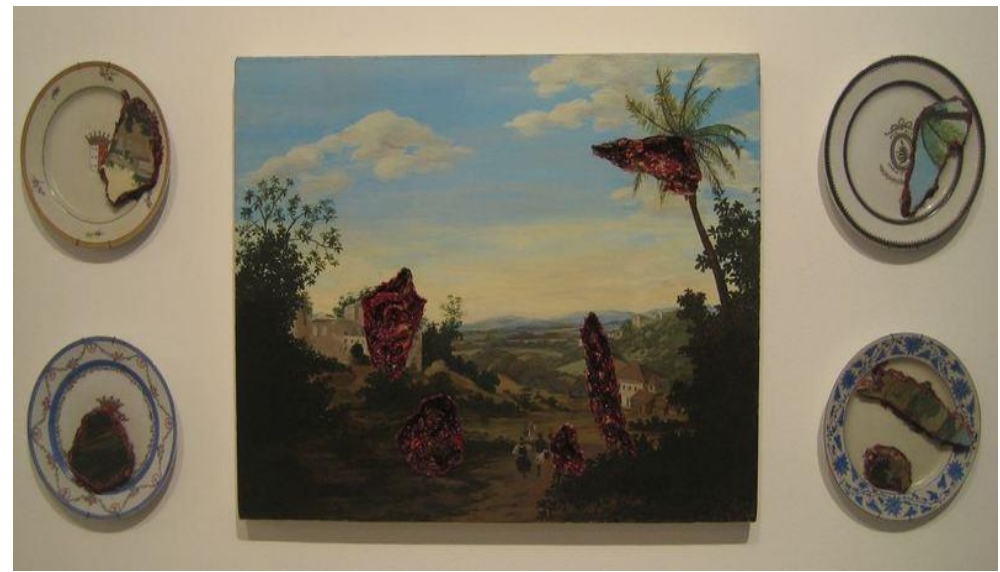

Figura 6 - Adriana Varejão. Carne à Moda de Frans Post, 1996 Reprodução fotográfica autoria desconhecida. CARNE à Moda de Frans Post. In: ENCICLOPÉDIA Itaú Cultural de Arte e Cultura Brasileiras. São Paulo: Itaú Cultural, 2019. Disponível em:

$<$ http://enciclopedia.itaucultural.org.br/obra2709/carne-a-moda-de-frans-post>

Nesta operação, a história trágica da nossa colonização reaparece para além do olhar estrangeiro. O olhar contemplativo da paisagem harmoniosa é deslocado pela nova visibilidade traumática oferecida por Adriana Varejão. Nas palavras de Herkenhoff (1996b), cada imagem de Adriana Varejão é uma passagem para um tempo descontínuo e heterogêneo. Para ele, a tela Carne à moda de Frans Post confirma que a reconfiguração do passado não é mera reconstituição de uma época passada, mas a recuperação de uma história como capaz de compor validade atual. 


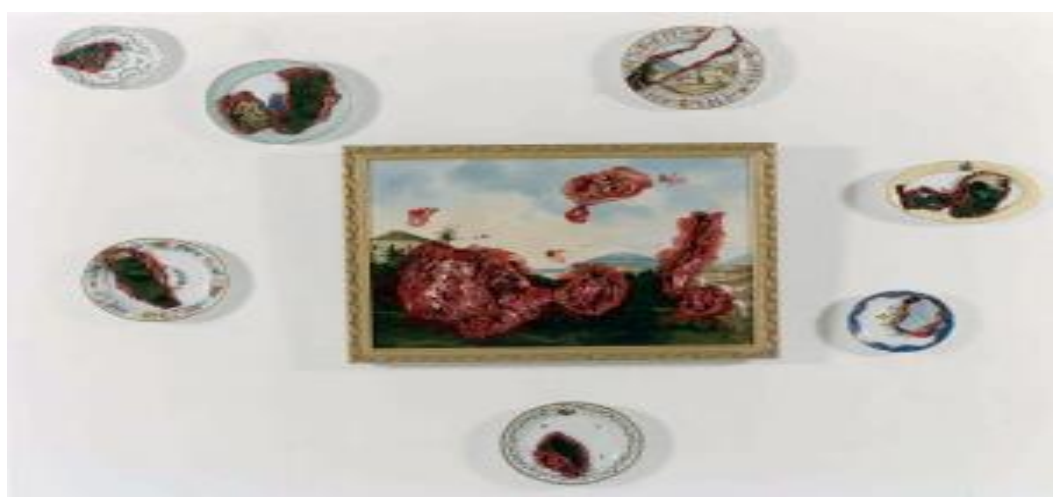

Figura 7 - Adriana Varejão. Carne à Moda de Taunay. Reprodução fotográfica autoria desconhecida. In: ENCICLOPÉDIA Itaú Cultural de Arte e Cultura Brasileiras. São Paulo: Itaú Cultural, 2019. Disponível em: <http://enciclopedia.itaucultural.org.br/obra2709/carne-a-moda-de-frans-post>

Já na reprodução da tela de Taunay, Varejão quase que desfigura totalmente a obra original com incisões e rasgaduras que, ao desfazerem uma aparente calma, se tornam capazes de mostrar a violência escondida por trás do projeto colonial português. Aqui também os nacos de carne são oferecidos em pratos de porcelana, tensionando a relação entre a memória iconográfica e o que realmente aconteceu.

No contexto de infração do modelo dominante das imagens do passado colonial e escravista, Varejão retoma ainda as gravuras de Jean-Baptiste Debret, pintor que também integrou a Missão Francesa de 1816, como seu colega Taunay, para fundar a Escola de Belas Artes no Rio de Janeiro. No seu processo de apropriação, a artista retira alguns personagens das gravuras de Debret para retratá-los em outra situação de violência e humilhação explícita. Na sua obra, Filho Bastardo II (1995), a escrava que aparece abanando a senhora na gravura de Debret, Um jantar brasileiro (1827), aparece na tela de Varejão sendo estuprada pelo senhor, o mesmo que, na imagem de Debret, está sentado na ponta da mesa.

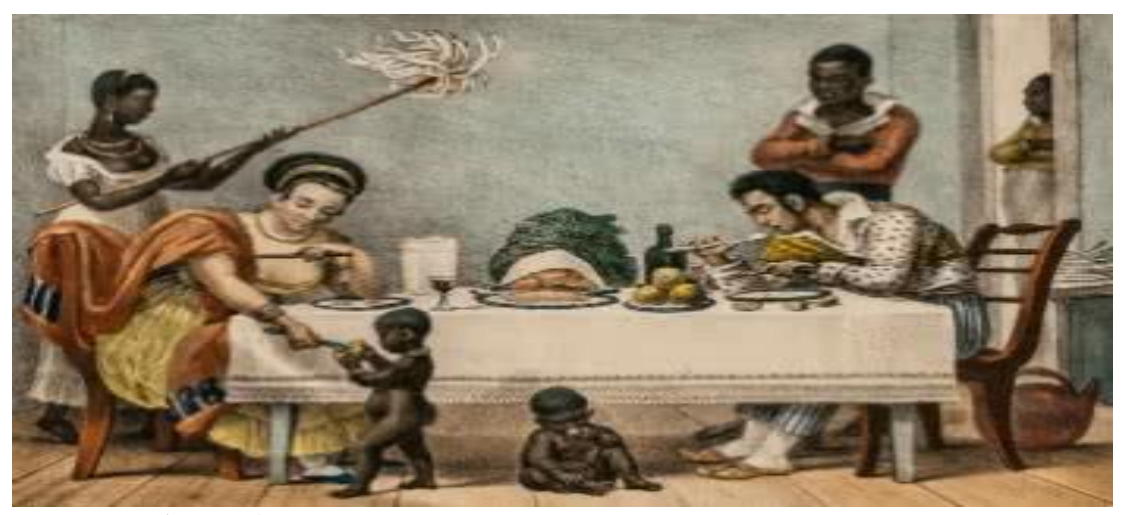

Figura 8 - Jean-Baptiste Debret. Um jantar brasileiro, 1827. https://commons.wikimedia.org/wiki/File 


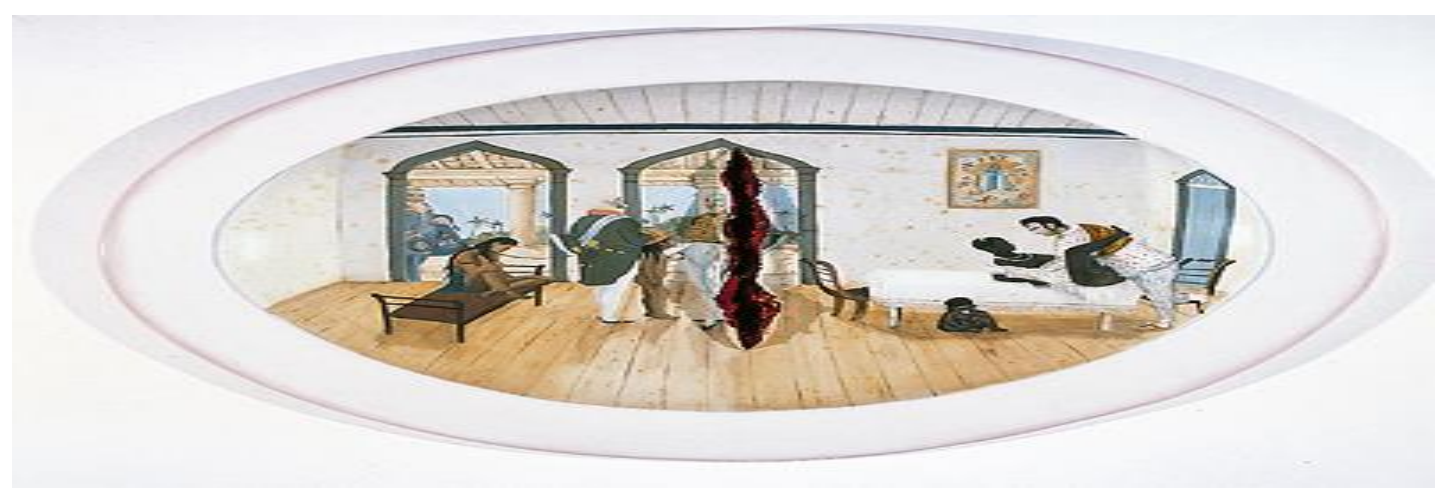

Figura 9 - Adriana Varejão. Filho Bastardo II - Cena de Interior.

http:/historiaporimagem.blogspot.com/2011/10/jean-baptiste-debret-um-jantar.html

A cena violenta contra a escrava negra se desenrola na mesma sala de jantar da imagem original. A naturalização da imagem de Debret é colocada em suspensão pelo gesto de inscrição da violência na representação pictórica oficial do cotidiano do Brasil colonial. Para Herkenhoff (1996b), Varejão inscreve sub-repticiamente suas próprias figuras para subverter a continuidade narrativa e reescrever a história. Nas suas palavras,

Na tela Filho Bastardo, figuras de Debret foram recontextualizadas em nova paisagem histórica, marcando a violência do processo de formulação étnica do Brasil. O que era esquecimento e opacidade na história torna-se visível. O processo de presentificação do passado é uma nova transparência (HERKENHOFF, 1996b, p. 3).

Adriana Varejão também faz uma profunda incisão vermelha no centro da sua pintura, e nos mostra as entranhas que a imagem de Debret não é capaz de revelar. Neste gesto, a narrativa histórica conhecida se subverte e problematiza a nossa herança patriarcal e escravocrata e toda a brutalidade existente contra os indígenas e negros escravizados no empreendimento colonial.

\section{Leila Danziger}

Outra artista que, no seu trabalho estético, vai caminhar entre ruínas, cacos e fragmentos é Leila Maria Brasil Danziger, nascida em 1962 na cidade do Rio de Janeiro. Pesquisadora e professora do Instituto de Artes da Universidade do Estado do Rio de Janeiro (UERJ), formou-se em Artes Plásticas pelo Institut des Arts Visuels, em Orleans, França, em 1989. É doutora em História Social da Cultura pela PUC do Rio de Janeiro e realizou seu pós- 
doutorado na Bezalel Academy of Arts and Design Jerusalém, em Israel. A artista apresenta como núcleo de sua poética a memória e o esquecimento.

Em uma série de trabalhos com o título de Diários públicos (2001-11), Danziger tem como proposta o apagamento seletivo das notícias de jornais impressos e o principal sentido dessa metodologia é denunciar e afastar o jornal de seu aspecto utilitário, de sua temporalidade linear e de sua tagarelice. A artista seleciona e arquiva jornais do Rio de Janeiro, cidade onde vive e de outras cidades onde já viveu como São Paulo, Tel Aviv ou Berlim. A operação de apagar os jornais se dá pela transferência do texto de uma superfície (a página) para outra superfície (o rolo de fita adesiva).

Durante o procedimento de extração, Danziger preserva algumas imagens fotográficas, por considerar que, ao permanecerem, essas imagens ganham um novo poder capaz de revelar a carga de histórias de violência diária, muitas vezes relegadas ao esquecimento. Depois do processo de extração, a artista elabora as próprias folhas de jornal, avulsas ou encadernadas em livros e, dessa maneira, a linguagem informativa dos jornais é desfeita e substituída por poemas, frases e imagens diversas. No procedimento de apagar palavras, manter imagens e inserir outros discursos, a artista ilumina a barbárie intrínseca da nossa sociedade da informação e preserva a memória daquilo que corre o risco de ser esquecido.

Walter Benjamin, em boa parte de seus ensaios, já refletia sobre o papel e o uso da linguagem como instrumento de alienação no mundo moderno e apontava para a necessidade de se reinventar uma linguagem que permitisse recuperar a realidade polifônica em diálogo profundo com o conhecimento e a compreensão do real. Em seu ensaio O Narrador considerações sobre a obra de Nikolai Leskov, Benjamin (1985) faz exatamente a denúncia da mediocridade da experiência no mundo moderno onde o que prevalece é a informação, uma forma de comunicação empobrecida e utilitária que nos leva ao culto do sempre novo. Novidade, brevidade, falta de conexão são as marcas da ditadura da informação que, segundo Benjamin, é uma forma de comunicação estranha e ameaçadora à arte de narrar. Para ele, ao contrário da narrativa, a imprensa não tinha como objetivo permitir ao leitor apropriar-se de suas informações como parte de sua experiência.

No seu transcurso poético, Leila Danziger também considera que o jornal não é capaz de transformar o fato em memória e experiência, pois seu ciclo de vida é absolutamente efêmero e, logo que aparece já se torna lixo e esquecimento. Assim, em seu trabalho estético, diferentes séries surgem a partir das imagens, palavras e versos carimbados nas folhas dos jornais apagados e reeditados. 


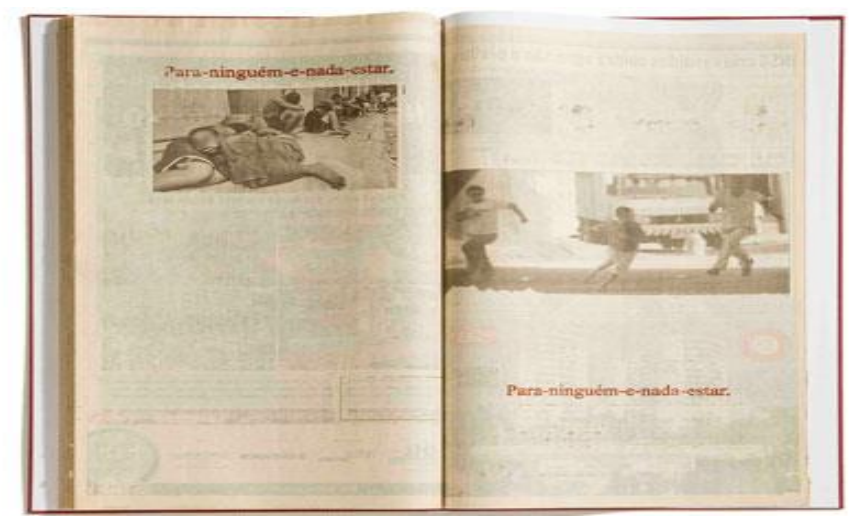

Figura 10 - Leila Danziger Série Diários públicos ("Para ninguém e nada estar"\#2), 2010.

Carimbo sobre jornal apagado e encadernação, 55 x 57.https://www.leiladanziger.net/blank-4

Neste processo, são criados novos espaços de inscrição, o excesso é apagado e o puramente utilitário é substituído pelo "murmúrio dos restos", pelas ruínas. Ou, como considera Costa (2013, p.85):

É preciso saber apagar o excesso para poder perceber a catástrofe que nos assola, a miséria que devasta o mundo com a falta de poesia, com o esquecimento da arte. É preciso que o espectador tome assento e demore no teatro da leitura delicadamente construída pela artista [...]. É preciso descobrir no vazio, na ausência, no silêncio os modos de ver o mundo aos pedaços.

\section{Para não esquecer jamais}

Em outro trabalho - Nomes Próprios - título de três exposições realizadas por Danzinger no período entre 1997 e 1998, a temática se refere ao Holocausto. Em depoimento da artista no catálogo Marcas do Corpo, Dobres da Alma (2000), ela explica que o que serviu de forte motivação ao seu trabalho foi o desejo de tirar os nomes da morte anônima, afastá-los da palavra "desaparecidos", humanizá-los, materializá-los e reinscrevê-los no tempo e no espaço.

As exposições foram apresentadas em um painel de $420 \times 200 \mathrm{~cm}$ formado por 76 gravuras em metal onde constam 76 nomes de judeus alemães com o mesmo sobrenome da artista. São todos desaparecidos e mortos nos campos de concentração nazistas da Segunda Guerra Mundial, e seus nomes foram copiados do Livro Lembrança, livro de memória da comunidade judaico-alemã que guarda uma imensa lista nominal dos judeus assassinados no Holocausto e que se encontra na biblioteca da comunidade judaica de Berlim, em Charlottenburg. 


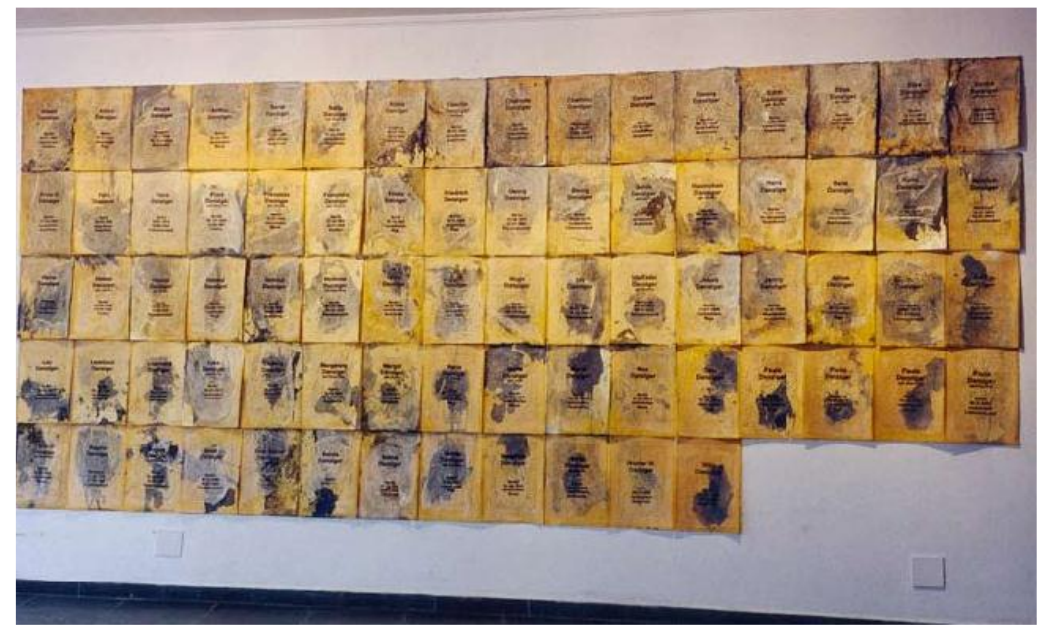

Figura 11 - Leila Danziger, Nomes próprios (detalhe), fotogravura sobre papel, óleo e grafite, $400 \times 220 \mathrm{~cm}, 1996 / 2000$ (Fonte: Portfólio on-line 2)https://www.leiladanziger.net/sobre-1-co6e

Além do nome e sobrenome, nada se sabe sobre essas pessoas. Cada gravura apresenta apenas o local e data da morte e a data do nascimento. Pelo local da morte, é possível talvez identificar um ou outro campo de concentração, mas não há referência à história do Holocausto e nenhum documento de arquivo acompanha a exposição. Nada é enunciado, não há fotos, imagens, somente nomes próprios e,cada um dos nomes, reverbera a sua condenação ao esquecimento.A série também é constituída por um conjunto de 12 livros confeccionados com imagens tiradas de jornais alemães e reproduzidas em serigrafia. Nos livros-cadernos que receberam o nome de Pallaksch Pallaksch, folhas de jornais apagadas e com novas impressões revelam, a partir da experiência traumática do Holocausto, os diferentes tipos de desamparo e de abandono do nosso mundo contemporâneo.

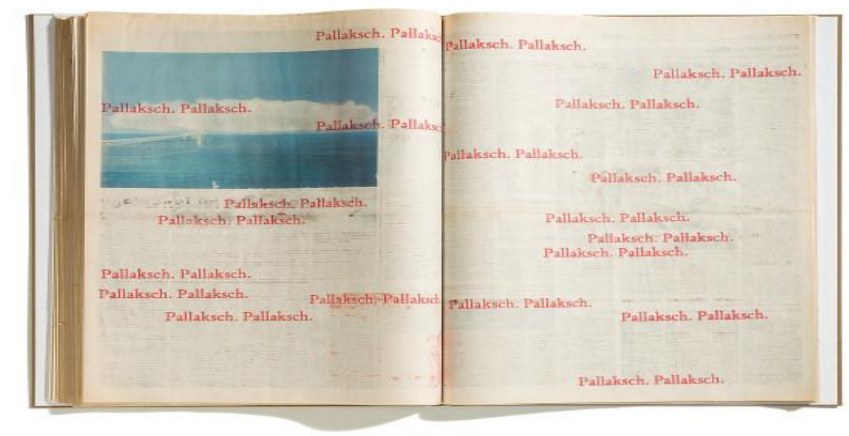

Figura 12 - Pallaksch Pallaksch [2010], carimbosobrejornaisapagados e encadernados, 80 x 58 (aberto), 66 páginas. https://www.leiladanziger.net/pallaksch-pallaksch

Para a artista, no poema de Celan, “Tübingen, Janeiro”, dedicado a Hölderlin, a língua é tida como um contínuo balbuciar: 


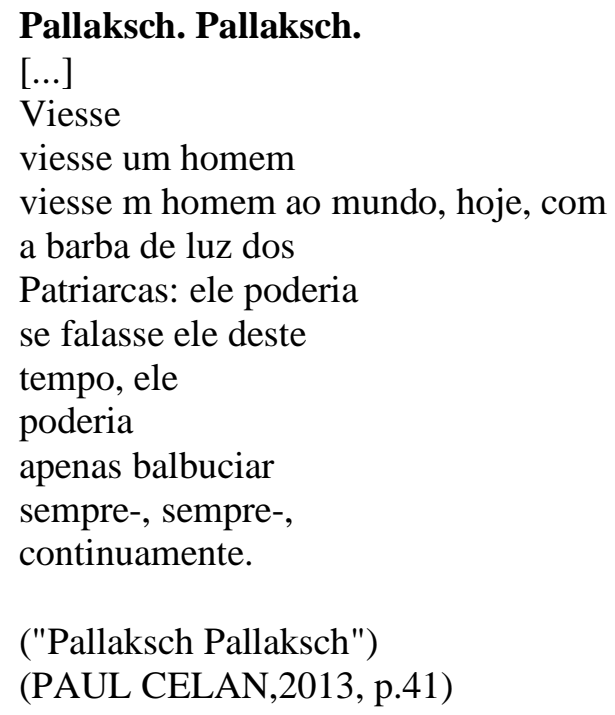

A sonoridade da palavra inventada por Hölderlin - Pallaksch, hesitante e ao mesmo tempo vigorosa, duplicada no poema de Celan, buscou conferir, de acordo com Leila Danziger (2013), sentidos à "escritura de resíduo e ruídos" (p.42) dos jornais. Danziger sustenta que lê Paul Celan há mais de vinte anos e a experiência resultante da leitura de seus poemas influenciou seu desejo "em apagar a fala ágil e incansável dos jornais e em seu lugar carimbar o incompreensível "pallaksch'. Ao explicar a presença de Celan em sua obra, Danziger afirma:

[...] apago os jornais, desfaço criteriosamente sua linguagem informativa e, em seu lugar, inscrevo extratos de poemas diversos, sobretudo de Paul Celan e de sua palavra obscurecida e resistente, a qual, deslocada do contexto de testemunho de Auschwitz, informa nossas pequenas e grandes catástrofes de cada dia (DANZIGER, 2013, p. 38).

Neste longo e cuidadoso processo de criação da artista, vemos que as intervenções buscam restituir com densidade a matéria banalizada e, ao mesmo tempo, se constituem como interpelação crítica das narrativas, da história e da memória. A linguagem informativa é apagada e desfeita para fazer emergir novos conteúdos e percepções nas imagens e palavras que permanecem potentes. Neste procedimento, a memória ilumina a barbárie intrínseca da nossa modernidade e possibilita outras coordenadas e escrituras.

\section{Percursos para uma educação política da memória no ensino da história}

O ensino de história se constitui como um campo de produção de conhecimento tanto na área de educação como na área de história e está atento às questões postas pela historiografia, 
pelo campo educacional e pelas demais ciências humanas. Hoje, seus diversos aportes teórico-metodológicos e suas novas temáticas avançaram na direção de novos conceitos tais como cultura escolar, saber escolar, saber docente e, desde a década de 1990, intensificouse a discussão sobre os processos de formação de uma consciência histórica (cognição histórica). Mas, se por um lado, muitas pesquisas se voltaram para as questões do simbólico, das representações, do discurso, trazendo abordagens mais plurais na construção do conhecimento histórico escolar, por outro, temos a permanência de concepções hegemônicas que remontam à constituição de uma escola normatizadora e com referencial epistemológico voltado ao paradigma moderno de ciência e conhecimento. Esta abordagem tradicional da história foi suficientemente forte no sentido de se fixar como elemento da cultura escolar cujos resquícios perpetuam-se até hoje.

Neste sentido, o campo do ensino da história muitas vezes não consegue significar a memória como resistência, como lugar dos rastros do que foi deixado para trás pelas narrativas oficiais e problematizar a memória enquanto percepção e apresentação daquilo que poderia ter acontecido. Ao silenciar outras narrativas, esta história se torna engessada e institui uma memória sujeita a silêncios: nenhuma memória das barbáries coloniais, das violências do Estado, das exclusões cotidianas, tanto do passado como do presente.

Ao buscarmos os procedimentos metodológicos e a força explicativa da arte contemporânea para expressar o real, consideramos a importância das discussões referentes ao tempo histórico e à escrita da história, capazes de revelar as escolhas entre o que lembrar e o que esquecer. A história tal como aconteceu, com sua narrativa prisioneira da armadilha da causalidade, se dilui no encontro de outros pressupostos teóricos. Discutir o lugar da memória a partir das experiências traumáticas do século $\mathrm{XX}$ significa, portanto, voltar a politizar o saber sobre o passado e o presente, como tão bem nos apresentam Rosangela, Adriana e Leila. Ao trabalhar a memória como lugar capaz de atualizar o passado no presente (memória do porvir do pretérito), a arte contemporânea tem conseguido realizar vários procedimentos que podem nos ajudar a pensar novos caminhos teóricos e metodológicos que tragam formas de saber diferentes do apenas racional, objetivo, fora de nós, impessoal, instrumental, linear, cronológico. Caminhos que nos instigam a mudar as coordenadas do representável e da nossa percepção dos acontecimentos sensíveis.

Como primeiro passo para estas mudanças, devemos destacar que muitas das nossas práticas sociais contemporâneas marcadas pelo culto do sempre novo e por um presentismo constante são reflexos do tempo cronológico, linear e dominante responsável pela impossibilidade de uma relação significativa com o passado.

Sabemos que a relação entre presente, passado e futuro é profundamente histórica. Hartog (2013) nomeia como regime de historicidade a "expressão de uma ordem dominante do tempo" (Hartog, 2013, p.139), ou seja, uma maneira de ordenar e articular o passado, presente e futuro para dar-lhes sentido. No século XX, de acordo com o autor, principalmente a partir da década de 1960, desintegram-se as ilusões em relação ao futuro e todas as perguntas vão procurar abrigo no presente - o presente presentista, fechado para a sobrevivência diária, um presente estagnante e um futuro percebido como ameaça. O tempo 
transformado em mercadoria busca por inovações e sem olhar para o passado, volta-se para si mesmo como presente absoluto. Nas palavras de Hartog,

Nessa progressiva invasão do horizonte por um presente cada vez mais inchado, hipertrofiado, é bem claro que o papel motriz foi desempenhado pelo desenvolvimento rápido e pelas exigências cada vez maiores de uma sociedade de consumo na qual as inovações tecnológicas e a busca de benefícios cada vez mais rápidos tornam obsoletos as coisas e os homens, cada vez mais depressa (HARTOG, 2013, p. 147-148).

Por outro lado, para este autor, desde meados dos anos de 1970, é possível observar uma fenda acontecendo neste presente presentista. No contexto de fugacidade das imagens na tela e da imaterialidade das comunicações, monumentos, museus e seus objetos, por oferecerem a materialidade negada pela televisão e trazerem alternativas aos discursos de memória apresentados pela mídia, voltam a ser ressignificados. Novos temas como ecologia, vida local, preservação de espécies de animais, conservação de objetos, defesa dos direitos humanos entre outros, começam a surgir como mobilizadores de ideias e ações. Já inquieto, como diz Hartog (2013), "o presente descobre-se igualmente em busca de raízes e de identidade, preocupado com a memória e genealogias" (Hartog, 2013, p. 151).

Neste contexto, a exigência da rememoração é duplamente atual: alude ao nosso presente e precisa se tornar ato. A rememoração, como confirma Hartog (2013), foi um dos conceitos mais importantes para Walter Benjamin. Rememorar, dizia ele, consiste em mergulhar nas profundezas do passado como o pescador de pérolas. Sem querer desnaturar a metáfora benjaminiana, é bom lembrar que o pescador de pérolas tradicional mergulha em locais profundos e não conta com nenhum instrumento que o ajude neste empreendimento (escafandro, máscara, tanque de oxigênio, vestimenta especial etc.), mas apenas com o seu desejo, seu fôlego e suas mãos. A rememoração, portanto, é ativa, um surgimento voluntário do passado no presente, com potencialidades para transformá-lo.

Logo, a construção deste caminho metodológico da rememoração implica o processo de ensinar a pensar historicamente para encontrar os indícios de outras histórias e sensibilidades no tempo dominante da história hegemônica. Aqui podemos confirmar a importância da concepção de tempo de Walter Benjamin, que nos fala do tempo do agora e do tempo da memória. Um tempo capaz de salvar do esquecimento a memória daquilo que teve lugar um dia. Memória entendida, como afirma Walter Benjamin (1987), não como um instrumento para se explorar o passado, mas sim como o seu próprio palco. Nas suas palavras,

[...] a memória é o meio daquilo que vivemos, assim como a terra é o meio dentro do qual jazem, soterradas, as cidades mortas. Quem pretende se aproximar do seu próprio passado soterrado tem de proceder como um homem que cava [...]. E, sem dúvida, para ter sucesso nas escavações, é preciso um plano. Igualmente indispensável, porém, é a enxada cautelosa e experimental na terra escura, e privase do melhor, quem só registra o inventário dos seus achados, e não a obscura 
felicidade do local do achado. A busca, mesmo em vão, é tão importante quanto o achado feliz.(BENJAMIN, 1987, p. 239)

Cabe confirmar, neste processo, a rede conceitual que nos leva a defender uma educação política da memória. Como a memória não se enquadra nos pressupostos teóricos e metodológicos de nenhuma disciplina em particular, o campo teórico da arte contemporânea nos ajuda a expressar uma ética e um posicionamento político em relação à nossa história. Destacamos a afirmação de Rancière (2014) de que as estratégias dos artistas para realizar o trabalho da ficção, não como um mundo imaginário oposto ao real, mas como trabalho que realiza dissensos, que muda as coordenadas das representações, os modos de apresentação sensível e as formas de anunciação, cria uma "paisagem inédita do visível, formas novas de individualidades e conexões, ritmos diferentes de apreensão do que é dado, escalas novas" (Rancière, 2014, p. 59).

Desta perspectiva, existe sentido em refletir sobre as potencialidades de uma educação política da memória. Uma memória que permita o nosso encontro com aquilo que poderia ter sido e com nosso desejo de atualização do passado. É com esta memória que podemos evocar e recordar as ruínas da história e realizar esperanças em um mundo onde seja possível pensar, viver e sonhar para além da barbárie e da razão instrumental.

O que importa neste processo são os elementos fundantes de novas reflexões e abordagens sobre o nosso passado capazes de trazer à tona histórias implícitas e não contadas, pouco visitadas pela historiografia oficial. Memórias na perspectiva de uma didática da história como embate, corpo a corpo, com narrativas fortes, realistas e esteticamente interessantes sobre a nossa real identidade e a nossa história. Neste sentido, justifica-se a busca por imagens dialéticas, ambivalentes, em vias de desaparecimento, com conotações políticas explícitas e comprometidas com dimensões mais inteiras dos seres humanos no presente.

Ao nos debruçarmos sobre as obras selecionadas, foi possível perceber como o campo teórico da arte contemporânea tem conseguido, nas suas diversas poéticas, expressar uma ética e um posicionamento político em relação à história e ampliar as discussões sobre os princípios epistemológicos, metodológicos e políticos na confluência entre a experiência do passado e os fatos atuais. Consideramos, assim, que os procedimentos de abordagem das fotografias, das imagens, do simbólico, entre outros, oferecidos pela dimensão estética, ajudam-nos a pensar o ensino da história não apenas como disciplina, mas como percepção racional, crítica e sensível sobre o mundo.

A educação política da memória amplia o que entendemos por educação histórica nos seus modos de explicação, compreensão, expressão e inserção nas questões culturais e de identidade, não apenas com as referências exclusivas da operação histórica, mas com as de outros espaços de circulação do sensível e do visível.

Os trabalhos selecionados das três artistas plásticas brasileiras - Rosângela Rennó, Adriana Varejão e Leila Danzinger, foram especialmente os que apresentavam narrativas sobre a condição humana e tematizavam a memória e o esquecimento social. Interessou-nos estabelecer uma reflexão sobre os usos sociais do passado em espaços mais amplos que o da 
academia, tendo, como objeto de estudo e reflexão, as abordagens sobre memória, história e esquecimento presentes hoje na arte contemporânea. É neste campo de análise e considerando o ensino da história não apenas como disciplina, mas como percepção racional e sensível sobre o mundo, que acreditamos ser possível fortalecer uma educação política da memória capaz de movimentar, a partir do presente, outras formas de ver, sentir, pensar e agir.

Ao olhar as imagens dos candangos de Rosangela Rennó, nos deparamos com estruturas discursivas capazes de revelar o não dito e acompanhamos os movimentos constitutivos de histórias que clamam por visibilidade. Com as páginas dos jornais de Leila Danziger, descobrimos as potencialidades de resistir pela linguagem poética e pelas imagens sobreviventes, ao mundo da informação, da brevidade e do esquecimento. Com as pinturas de Varejão, fomos ao encontro de novas representações e novos discursos com o propósito de tecer constelações que ligam o presente ao passado e possibilitara insurgência de "memórias a contrapelo", que provoquem deslocamentos nas narrativas e apresentem elementos fundantes de novas reflexões e abordagens sobre o nosso passado.

Ao nos voltarmos para os procedimentos estéticos e metodológicos adotados por essas artistas contemporâneas para tratar a memória no Brasil, nos deparamos com traços - forças vivas e potentes - capazes de fortalecer uma perspectiva pedagógica de conciliação entre a prática investigativa e a conscientização dos silêncios da história.Assim poderemos falar de uma educação política da memória e de novos caminhos teórico-metodológicos em diversas modalidades formais e não formais de um ensino capaz de promover a inclusão social e fortalecer as lutas pelos direitos humanos e pela cidadania.

\section{Notas}

1. Disponível em: http://www.troiades.com.br e também na edição impressa pela Editora Patuá.

2. "Genocide - Symphonic Holocaust" faz parte do álbum Blutund Nebel (2005), de Maurizio Bianchi.

3. Destacamos a História Cultural que, a partir de diálogos com a Antropologia, a Linguística, a Psicologia e a Política, possibilitou novas abordagens e posturas epistemológicas específicas a partir dos conceitos de representação, imaginário, narrativa, ficção e sensibilidades.

4. A inscrição da violência, nas mais diferentes manifestações artísticas, significando a destruição e o sofrimento no nosso processo histórico.

5. Expressão usada por Walter Benjamin nas suas Teses sobre o Conceito da História (1940), e que pode ser interpretada como sendo a história concebida a partir do ponto de vista dos vencidos em oposição à história oficial do progresso.

6. Educação histórica entendida como a busca por caminhos teórico-metodológicos ancorados na própria ciência da história e entendida enquanto prática social.

7. Walter Benjamin (1985) definiu assim a estética do pintor suíço: “Tanto um pintor complexo como Paul Klee quanto um arquiteto programático como Loos rejeitam a imagem do homem tradicional, solene, nobre, adornado com todas as oferendas do passado, para dirigir-se ao contemporâneo nu, deitado como um recém-nascido nas fraldas sujas de nossa época" (p.116).

8. Sobre este acontecimento, conferir em Monteiro (2016, p.122) a narração do contexto do massacre. Sua referência foi o livro "Construtores de Brasília”, de Nair Heloisa Bicalho de Souza (1983). 


\section{Referências bibliográficas}

ASSMAN, Aleida. Espaços da recordação. Formas e transformações da memória cultural. Campinas (SP): Editora da Unicamp, 2011.

BENJAMIN, Walter. Teoria do conhecimento, teoria do progresso. In: Passagens. Tradução de Irene Aron e Cleonice Paes Barreto Mourão. Belo Horizonte: Editora da UFMG; São Paulo: Imprensa Oficial do Estado de São Paulo, 2007, p. 499-530.

BENJAMIN, Walter. Sobre o conceito da história. In:___. Obras escolhidas. Magia e técnica, arte e política. Tradução de Sergio Paulo Rouanet. São Paulo: Brasiliense, 1985, p. 222-232. (vol. 1)

O narrador. Considerações sobre a obra de Nikolai Leskov. Obras escolhidas. Magia e técnica, arte e política. Tradução de Sergio Paulo Rouanet. São Paulo: Brasiliense, 1985, p. 197-221. (vol. 1)

Imagens do pensamento. In: Obras escolhidas. São Paulo: Brasiliense, 1987, p. 143-277. (vol. 2)

BARBERENA, Ricardo. Quando os operários mortos visitam Brasília: os espectros fotográficos em Imemorial, de Rosangela Rennó. Revista Poiésis, n.13, p. 93-104, Ago. 2009.

COSTA, Luiz Cláudio da. Diários públicos - o teatro da leitura. In: DANZIGER, Leila. Diários públicos. Sobre memória e mídia. Rio de Janeiro: FAPERJ/contracapa, 2013, p. 82-90.

DANZIGER, Leila. Diários públicos: sobre memória e mídia. Rio de Janeiro: FAPERJ/Contra Capa, 2013.

Pallaksch Pallaksch. In:

Diários públicos. Sobre memória e mídia. Rio de Janeiro: FAPERJ/contracapa, 2013, p. 41-46.

Diários públicos. O jornal e o esquecimento. Revista Visualidades, Goiânia, 2007, p. 80 - 91.

Depoimento da artista no catálogo "Marcas do corpo, dobras da alma", XII Mostra da Gravura de Curitiba. 2000

DIDI-HUBERMAN, Georges. Diante do tempo. História da arte e anacronismo das imagens. Belo Horizonte: Editora da UFMG, 2015.

. Sobrevivência dos vaga-lumes. Belo Horizonte: Editora da UFMG, 2011.

DOS ANJOS, Moacir. Mesmo diante da imagem mais nítida. In: RENNÓ, Rosângela. Folder de exposição, Recife, 2006.

FLORES, Guilherme Gontijo -Troaides.remix para o próximo milênio.Disponível em [http://www.troiades.com.br],2014.

GAGNEBIN, Jeanne Marie. Obra. Limiar, aura e rememoração. Ensaios sobre Walter Benjamin. São Paulo: editora 34, 2014.

História e narração em Walter Benjamin. São Paulo: Perspectiva, 1999.

HARTOG, François. Regimes de Historicidade. Presentismo e experiências do tempo. Belo Horizonte: Editora Autentica, 2013.

HERKENHOFF, Paulo. Rennó ou a beleza e o dulçor do presente. In Rosângela Rennó. Edup.São Paulo, 1996 a. Disponível em: www.rosangelarenno. Acesso em: 01 fev. 2017.

Pintura/satura. In Adriana Varejão. São Paulo: Galeria Camargo, 1996 b. Disponível em: <www.adrianavarejao.net/pt-br/saunas>. Acesso em: 01 fev. 2017.

HUYSSEN, Andreas. Culturas do passado-presente. Modernismos, artes visuais, políticas da memória. Rio de Janeiro: Contraponto/Museu de Arte do Rio, 2014.

MONTEIRO, Charles. Documento, memória e arquivo na arte contemporânea: algumas reflexões sobre a obra fotográfica Imemorial de Rosangela Rennó. Revista Memória em Rede, Pelotas, v. 8, n. 14, jan/jun 2016.

RANCIÈRE, Jacques. O espectador emancipado. Tradução de Ivone C. Benedetti. São Paulo: WMF, 2014.

RENNÓ, Rosângela. Rosângela Rennó (Depoimento). Belo Horizonte: C/Arte, 2015. 
RIBEIRO, Gustavo Silveira. O choro triste da história. Revista Cult, São Paulo, p.1-5, março, 2017.Disponível em: <http://revistacult.uol.com.br/home/o-choro-triste-da-historia/>. Acesso em: 06 set. 2017.

SARLO, Beatriz. Tempo Passado: cultura da memória e guinada subjetiva. São Paulo: Companhia das Letras; Belo Horizonte: UFMG, 2007.

SELIGMAN-SILVA, Márcio. O imperativo dos traços. Revista Cult, São Paulo, n. 197, p.31-35, dez. 2014a. Sobre o anarquivamento - um encadeamento a partir de Walter Benjamin. Revista Poiésis, n. 24, p. 35-58, dez. 2014b.

TORINHO, Maria Esther. Uma poética do silêncio: trauma, representação e linguagem em "Fuga da morte", de Paul Celan. Anu. Literário, Florianópolis, v.19, n. 2, p.107-122, 2014.

\section{Correspondência}

Claudia Regina Prado Fortuna: Mestrado e Doutorado em Educação pela Universidade Estadual de Campinas - UNICAMP. Pós - Doutorado em Educação pela Universidade de São Paulo - USP. Docente do Departamento de História da Universidade Estadual de Londrina.

E-mail: claudiafortuna@uel.br

Texto publicado em Currículo sem Fronteiras com autorização da autora 